\title{
Interleukin 10-Secreting MSCs via TALEN- Mediated Gene Editing Attenuates Left Ventricular Remodeling after Myocardial Infarction
}

\author{
Die Meng $^{\mathrm{a}}$ Seongho Han ${ }^{\mathrm{a}}$ In Sil Jeong ${ }^{\mathrm{b}}$ Sung-Whan Kim ${ }^{\mathrm{b}, \mathrm{c}}$ \\ aDepartment of Family Medicine, College of Medicine, Dong-A University, Busan, Republic of Korea, \\ bInstitute for Bio-Medical Convergence, Department Medicine, Catholic Kwandong University College \\ of Medicine, Gangneung, Republic of Korea, 'Catholic Kwandong University International St. Mary's \\ Hospital, Incheon, Republic of Korea
}

\section{Key Words}

Acute myocardial infarction - Anti-inflammation - Amniotic mesenchymal stem cells $•$ Cardiac remodeling $\cdot$ Genome editing

\begin{abstract}
Background/Aims: Stem cells or progenitor cells have been demonstrated as a novel alternative for cell therapy; however, their sustained efficacy is still debated. This study aimed to evaluate whether interleukin 10 (IL-10) gene-edited amniotic mesenchymal stem cells (AMM/I) contribute to left ventricular (LV) function and remodeling after acute myocardial infarction (AMI). Methods: The IL-10 gene was integrated into the genomic locus of AMM via transcription activator-like effector nucleases (TALEN) and AMM/I were intramyocardially transplanted into AMI mice models. Cardiac function, quantitative polymerase chain reaction, histology, capillary density, and apoptosis assays were performed. Results: AMM/I transplantation significantly suppressed infiltrated CD68 positive or F4/80 positive inflammatory cells and reduced the expression of pro-inflammatory factors in the infarcted myocardium. In addition, significantly improved LV function and reduced infarct size was noted in mice model with AMM/I transplantation than in those given AMM. Moreover, AMM/I highly inhibited cell apoptosis and increased capillary density in the infarcted myocardium. Conclusion: Our study demonstrated that $\mathrm{AMM} / \mathrm{I}$ recruitment played favorable roles in the early restoration of LV function and remodeling by suppressing inflammation and enhancing cardiac protection and capillary density.
\end{abstract}




\section{Cellular Physiology Cell Physiol Biochem 2019;52:728-741 \\ \begin{tabular}{ll|l} 
and Biochemistry & $\begin{array}{l}\text { DOl: 10.33594/000000051 } \\
\text { Published online: 29 March 2019 }\end{array}$ & $\begin{array}{l}\text { O 2019 The Author(s). Published by } \\
\text { Cell Physiol Biochem Press GmbH\&Co. KG }\end{array}$ \\
\cline { 2 - 3 }
\end{tabular} \\ Meng et al.: IL-10 Edited MSCs Attenuates Left Ventricular Remodeling}

\section{Introduction}

In Western societies, myocardial infarction (MI) is a major cause of death owing to the development of heart failure. One of the major pathologic determinants of cardiac diseases has been noted to be left ventricular (LV) remodeling due to fibrosis and dilation, leading to cardiac dysfunction and heart failure. This cardiac dysfunction has a strong association with inflammation in the heart $[1,2]$. Pro-inflammatory cytokines and anti-inflammatory cytokines mediate homeostasis in damaged heart; however, sustained exposure to proinflammatory response could lead to heart failure owing to its association with increased matrix metalloproteinase production and extracellular matrix degradation $[3,4]$. Thus, therapeutic strategies targeting inflammatory activity in heart disease have been applied to reduce cardiac remodeling [5].

According to recent reports, stem cells contribute to tissue regeneration by paracrine effects or transdifferentiation [6,7]. In addition, several studies have demonstrated that mesenchymal stem cells (MSCs) have anti-inflammatory properties via interleukin (IL) 10 and IL-1 receptor antagonist (IL-1Ra) secretion [8, 9]. IL-10 is one of the potent antiinflammatory factors that controls neutrophilic infiltration and deactivates various proinflammatory mediators [10]. In fact, paracrine factors secreted from MSCs facilitate favorable therapeutic outcomes [8,9]. However, the low level of paracrine factors appears to be inadequate for efficient therapeutic efficacy due to the short half-life of paracrine proteins, which poses a big challenge for stem cell research and regenerative medicine.

Recently, genome-editing technology using clustered regularly interspaced short palindromic repeat-associated (Cas) systems or transcription activator-like effector nucleases (TALENs) has been regarded as an attractive tool to generate functionally improved stem cells. This technology can target specific genomic sites such as the adenoassociated virus integration site 1 (AAVS1), which is an open chromosomal state and one of the safe harbor sites in the PPP1R12C gene of human chromosome 19 [11]. TALENs, which are artificial restriction enzymes, have strong and specific protein-to-nucleotide recognition and can bind as a pair-on sequences in the genomic site to generate a double-strand break (DSB) [12]. The introduction of DSB allows for the modification of the genome via homologydirected repair (for knock-in) or non-homologous end joining for the introduction of targeted mutagenesis such as an insertion or deletion (indel) [12].

In this study, we developed a long-term $I L-10$-secreting system at the safe harbor genomic locus of amniotic mesenchymal stem cells (AMMs) via TALEN-mediated editing. In addition, we evaluated whether interleukin $10(I L-10)$ gene-edited amniotic mesenchymal stem cells (AMM/I) contribute to left ventricular (LV) function and remodeling after acute myocardial infarction (AMI).

\section{Materials and Methods}

\section{Cell culture}

Human AMMs were purchased from Thermo Fisher Scientific, Inc. (Waltham, MA, USA). AMMs were cultured in low-glucose Dulbecco's modified Eagle medium (DMEM; Gibco, Grand Island, NY, USA) supplemented with $10 \%$ fetal bovine serum (FBS), $100 \mathrm{U} / \mathrm{mL}$ penicillin, and $100 \mu \mathrm{g} / \mathrm{mL}$ streptomycin (Gibco).

\section{Donor construction}

IL-10 was synthesized and inserted into the AAVS1 safe harbor site targeting donor vector (System Biosciences, Palo Alto, CA, USA) at the NdeI and SalI restriction sites. 


\section{Cellular Physiology Cell Physiol Biochem 2019;52:728-741 \\ \begin{tabular}{l|l} 
DOl: 10.33594/000000051 & a 2019 The Author(s). Published by \\
Cell Physiol Biochem Press GmbH\&Co. KG
\end{tabular} \\ Meng et al.: IL-10 Edited MSCs Attenuates Left Ventricular Remodeling}

\section{Transfection and selection}

Human AMMs were maintained in DMEM supplemented with 10\% FBS. For electroporation, human AMMs were harvested and counted; $1 \times 10^{5}$ cells were resuspended with $0.6 \mu \mathrm{g}$ of AAVS1 left TALENuclease vector (System Biosciences), AAVS1 right TALE-Nuclease vector (System Biosciences) and AAVS1 HR Donor (System Biosciences) in $10 \mu \mathrm{L}$ electroporation buffer, and the cells were electroporated using a Neon Transfection System (Thermo Fisher Scientific). After 4 days of transfection, IL-10 knock-in cells were selected by incubating them in $5 \mu \mathrm{g} / \mathrm{mL}$ puromycin for 7 days.

\section{Fluorescence-activated cell sorting}

After puromycin selection, the cells were harvested on day 50. Cells were washed once with phosphatebuffered saline (PBS) following the $0.05 \%$ trypsin/EDTA treatment for cell detachment. The cells were resuspended in PBS for sorting. The cells were sorted on an S3e Cell Sorter (Bio-Rad, Hercules, CA, USA).

Genomic DNA extraction and junction polymerase chain reaction

Genomic DNA from cultured cells was extracted using a G-spin ${ }^{\mathrm{TM}}$ Total DNA Extraction Mini Kit (Intron Biotechnology) according to the manufacturer's instructions. Next, $120 \mathrm{ng}$ of genomic DNA was amplified by touch-down polymerase chain reaction (PCR) (36 cycles). The touch-down PCR conditions were as follows: 1 cycle at $98^{\circ} \mathrm{C}$ for $30 \mathrm{~s}$, followed by 22 cycles of $98^{\circ} \mathrm{C}$ for $30 \mathrm{~s}, 72-60^{\circ} \mathrm{C}$ for $30 \mathrm{~s}$ (a decrease of $1^{\circ} \mathrm{C}$ every two cycles) and $72{ }^{\circ} \mathrm{C}$ for $1 \mathrm{~min}$, followed by 14 additional cycles at $98^{\circ} \mathrm{C}$ for $30 \mathrm{~s}, 60^{\circ} \mathrm{C}$ for $30 \mathrm{~s}$, and $72^{\circ} \mathrm{C}$ for $1 \mathrm{~min}$, and the final extension step at $72^{\circ} \mathrm{C}$ for $10 \mathrm{~min}$. For the second PCR, $0.5 \mu \mathrm{L}$ of the touch-down PCR product was used. The second PCR conditions were as follows: 1 cycle at $98^{\circ} \mathrm{C}$ for $30 \mathrm{~s}$, followed by 35 cycles at $98^{\circ} \mathrm{C}$ for $30 \mathrm{~s}, 65^{\circ} \mathrm{C}$ for $30 \mathrm{~s}$, and $72^{\circ} \mathrm{C}$ for $1 \mathrm{~min}$, with a final extension step at $72^{\circ} \mathrm{C}$ for $10 \mathrm{~min}$. PCR primer were used as following; Forward (J212) : aactctgccctctaacgctg, (J195) : cgaggccagaggccacttgtgta.

Quantitative reverse transcriptase-PCR ( $q R T-P C R)$ and reverse transcriptase-PCR (RT-PCR) analyses qRT-PCR or RT-PCR analysis was conducted as described in a previous study [13-15]. Briefly, the total RNA was isolated from the cells using RNA-stat (Iso-Tex Diagnostics, Friendswood, TX, USA). The extracted RNA was reverse-transcribed using Taqman Reverse Transcription Reagents (Applied Biosystems, Foster City, CA, USA), according to the manufacturer's instructions. The synthesized cDNA was subjected to qRTPCR or RT-PCR using human-specific primers and probes. RNA levels were quantitatively assessed using the ABI PRISM 7000 Sequence Detection System (Applied Biosystems). The relative mRNA expression normalized to GAPDH expression was calculated as described previously [16].

\section{qPCR and RT-PCR primer}

The primers used in qRT-PCR were for human IL-10 (Hs00237017_m1) and GAPDH (Hs99999905_ m1) and for mouse IL-1 $\beta$ (Mm00434228_m1, IL-6 (Mm00446190_m1), tumor necrosis factor $\alpha$ (TNF- $\alpha$ ) (Mm00443259_g1), monocyte chemoattractant protein 1 (MCP-1) (Mm00441242_m1), fibroblast growth factor-2 (FGF-2) (Mm01285715_m1), insulin growth factor-1 (IGF-1) (Mm00439561_m1), stromal cell-derived factor $1 \alpha$ (SDF-1 $\alpha$ ) (Mm00445552_m1), vascular endothelial growth factor A (VEGF-A) (Mm01281448_g1), and GAPDH (Mm99999915_g1). The following paired RT-PCR primers were used: GAPDH (Hs00761525_CE, 268 bp), IL-10 (Hs00564257_CE, 274bp). All of the primer/probe sets were purchased from Applied Biosystems.

\section{Microarray analysis}

Microarray analysis was performed using the Clariom S Human Array (Affymetrix, Santa Clara, CA, USA). The data were summarized and normalized with the robust multiaverage (RMA) method implemented in Affymetrix ${ }^{\circledR}$ Power Tools. We exported the results of the gene level RMA analysis and performed differentially expressed gene analysis. The statistical significance of the expression data was determined through fold change. Hierarchical cluster analysis was performed using complete linkage and Euclidean distance as a measure of similarity. 


\section{Cellular Physiology Cell Physiol Biochem 2019;52:728-741 \\ \begin{tabular}{l|l} 
DOl: 10.33594/000000051 & a 2019 The Author(s). Published by \\
and Biochemistry Physiol Biochem Press GmbH\&Co. KG
\end{tabular} \\ Meng et al.: IL-10 Edited MSCs Attenuates Left Ventricular Remodeling}

Enzyme-linked Immunosorbent Assay (ELISA)

$\mathrm{AMM}$ and $\mathrm{AMM} / \mathrm{I}\left(1 \times 10^{6}\right.$ cells each) were seeded into T-75 cell culture flasks and grown in normal medium or low-glucose DMEM (Gibco) containing 10\% FBS, $100 \mathrm{U} / \mathrm{mL}$ penicillin and $100 \mathrm{mg} / \mathrm{mL}$ streptomycin (Gibco) for $48 \mathrm{~h}$ until the cells reached approximately 80\% confluence. Culture media (CM) from each sample was then centrifuged at $1,000 \mathrm{xg}$ for $5 \mathrm{~min}$ and the supernatants were collected and used as CM. In vitro IL-10 secretion levels of AMM and AMM/I CM were assessed by using IL-10 ELISA kit (Abcam, Cambridge, MA, USA).

\section{Cell transplantation in MI models}

All experimental protocols were approved by the Dong-A University Institutional Animal Care and Use Committee and all procedures were performed in accordance with the Guide for the Care and Use of Laboratory Animals published by the US National Institutes of Health (NIH Publication No. 85-23, revised 1996). The AMI model was induced as described in previous literature [17]. Male athymic nude mice (Joongang Laboratory Animal Inc., Seoul, South Korea), aged between 7 to 10 weeks and weighing between 19 to $23 \mathrm{~g}$ were used. To induce AMI, the mice were anesthetized $(75 \mathrm{mg} / \mathrm{kg}$ ketamine, $1 \mathrm{mg} / \mathrm{kg}$ medetomidine, and $600 \mathrm{mg} / \mathrm{kg}$ atropine $)$ and were administered buprenorphine $(0.05 \mathrm{mg} / \mathrm{kg})$; the depth of anesthesia was monitored by the respiratory rate and lack of withdrawal reflex upon toe pinching. The mice were intubated with a 22-gauge intravenous catheter and artificially ventilated with a mechanical ventilator under anesthesia using isoflurane. After opening the chest, the left anterior descending artery was ligated using 8.0 polypropylene sutures. The apex of the LV was observed for evidence of akinesia and myocardial blanching, indicating interruption of coronary flow. After induction of MI, $1 \times 10^{6} \mathrm{AMM}, \mathrm{AMM} / \mathrm{I}$ in PBS (50 $\mu \mathrm{L}$ ), or the same volume of PBS alone, were directly injected into the peri-infarct areas (three sites). Cardiac function was examined using VisualSonics Vevo 2100 with a 40-MHz transducer (Visualsonics, Toronto, Ontario, Canada), and left ventricular ejection fraction (EF) and left ventricular fractional shortening (FS) were calculated as described previously [18]. Euthanasia was performed by intravenous injection of thiopental-sodium $(40 \mathrm{mg} / \mathrm{kg})$.

\section{Histological analysis}

Mice hearts were harvested and fixed for $4 \mathrm{~h}$ in $4 \%$ paraformaldehyde and incubated overnight in $15 \%$ sucrose solution. The tissues were embedded in OCT compound (Sakura Finetek, Torrance, CA, USA), snapfrozen in liquid nitrogen, and sectioned (thickness, 10-20 $\mu \mathrm{m}$ ) [19]. Tissue sections were permeabilized and stained with anti-CD68 (1:200; Serotec, Raleigh, NC, USA) and followed by secondary antibody. CD68positive cells, as number per high-power visual field, were assessed at randomly selected parts of the border zone of infarcted hearts. Nuclei were counterstained with 4',6-diamidino-2-phenylindole (1:5000; Sigma Aldrich, St. Louis, MO, USA). For capillary density measurement, five frozen sections of tissue from each group were stained with primary biotinylated ILB4 (1:250; Vector Laboratory Inc., Burlingame, CA, USA) and secondary strepta-avidin Alexafluor 488 (1:400; Invitrogen). Five fields from four tissue sections were randomly selected, and the number of capillaries was counted in each field. Photographs were taken using fluorescent inverted microscopy or confocal microscopy. To examine apoptosis, TdT-mediated dUTP nick-end labeling (TUNEL) reaction was conducted using fluorescein in situ cell death detection kit (RocheMolecular, Indianapolis, IN, USA) [20]. The fibrosis area and infarction area were examined by the computer software Image-Pro Plus after Masson's trichrome staining as previously described [21, 22].

\section{Statistical analysis}

All data were presented as mean \pm standard deviation. Statistical analyses were performed with Student's $t$ test for comparisons between two groups, and analysis of variance followed by Bonferroni's correction was performed for more than two groups using SPSS version 11.0 (IBM Corp., Armonk, NY, USA) $[14,15]$. A $p$ value $<0.05$ was considered statistically significant. Graphs were drawn using MedCalc software ${ }^{\circledR}$ (Mariakerke, Belgium). 


\section{Cellular Physiology Cell Physiol Biochem 2019;52:728-741 \\ \begin{tabular}{ll|l} 
and Biochemistry & $\begin{array}{l}\text { DOl: 10.33594/000000051 } \\
\text { Published online: 29 March 2019 }\end{array}$ & $\begin{array}{l}\text { O } 2019 \text { The Author(s). Published by } \\
\text { Cell Physiol Biochem Press GmbH\&Co. KG }\end{array}$ \\
\cline { 2 - 3 }
\end{tabular} \\ Meng et al.: IL-10 Edited MSCs Attenuates Left Ventricular Remodeling}

\section{Results}

Targeted knock-in of IL-10 into the AAVS1 safe harbor locus

To establish a stable stem cell line expressing the anti-inflammatory gene $I L$ - 10 using the TALEN-mediated integration method, we chose AAVS1, known as a safe locus for stable transgene expression, on chromosome 19 as the target integration site. The targeting donor plasmid DNA was designed to carry PGK promoter-driven $I L-10$ and EF1 $\alpha$ promoter-driven GFP-T2A-puromycin (Fig. 1A). The donor plasmid was transfected into human AMMs with a pair of TALENs, leading to cleavage of the AAVS1 locus. Although less than $6 \%$ of cells were GFP-positive cells after transfection, we increased the ratio of IL-10 knock-in GFP-positive cell to $99.6 \%$ by fluorescence-activated cell sorting and puromycin drug selection (Fig. 1C). To confirm the genomic integration of the donor plasmid into AAVS1, we performed genomic DNA PCR followed by touch-down PCR. The correct insertion of the donor plasmid was confirmed by $5^{\prime}$-junction fragment (960-bp) amplification (Fig. 1B). Next, we confirmed the $I L-10$ expression in transfected AMMs by qRT-PCR, which was significantly higher than that of AMM-untreated control cells, indicating the successful generation of AMM/I (Fig. 1D).

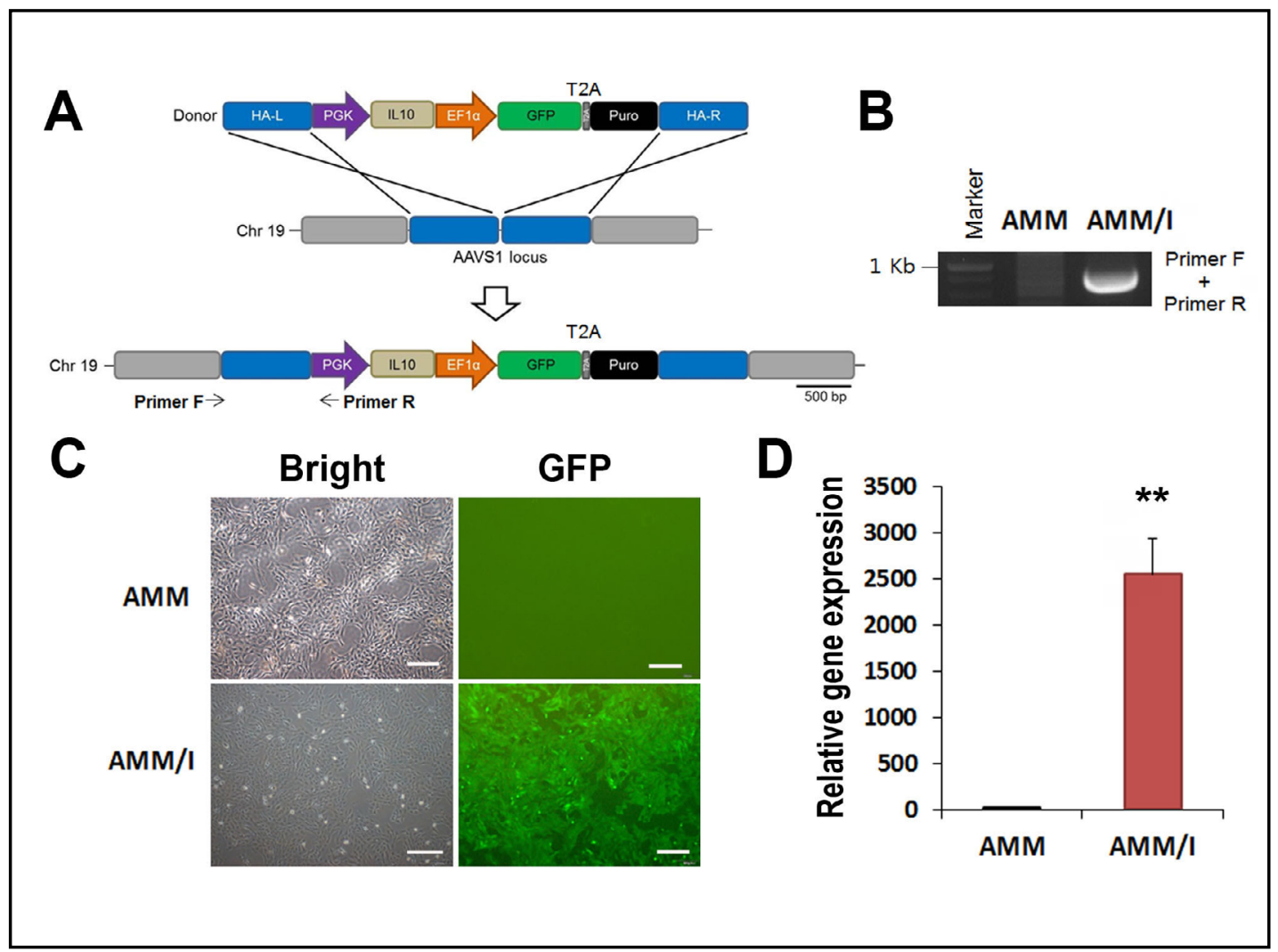

Fig. 1. Generation of the AMM/I cell line via TALEN. (A) Schematic diagram of the donor vector carrying IL-10 and donor plasmid DNA targeting locus (AAVS1 site). The expression cassette containing the PGK promoter-driven IL-10 and EF1 $\alpha$ promoter-driven GFP-T2A-puromycin were inserted into the AAVS1 site by homology-directed repair. The locations of primers for junction detection are indicated (primers F and R). HA-L, left homology arm; HA-R, right homology arm; PGK, phosphoglycerate kinase promoter; EF1 $\alpha$, elongation factor-1 alpha promoter; Puro, puromycin. (B) Identification of the correct insertion of the donor plasmid into the AAVS1 locus by junction PCR. (C) Representative picture of GFP expressing the transfected AMM/I line. Transfected cells were purified by puromycin and fluorescence-activated cell sorting. Bars $=200 \mu \mathrm{m}$. (D) Quantification of mRNA expression levels in the AMM/I cell line. ${ }^{* *} \mathrm{p}<0.01 ; \mathrm{n}=4$ per group. 


\section{Cellular Physiology Cell Physiol Biochem 2019;52:728-741 \\ \begin{tabular}{ll|l} 
and Biochemistry & $\begin{array}{l}\text { DOl: 10.33594/000000051 } \\
\text { Published online: 29 March 2019 }\end{array}$ & $\begin{array}{l}\text { O 2019 The Author(s). Published by } \\
\text { Cell Physiol Biochem Press GmbH\&Co. KG }\end{array}$ \\
\cline { 2 - 3 } &
\end{tabular} \\ Meng et al.: IL-10 Edited MSCs Attenuates Left Ventricular Remodeling}

Global gene expression profile of AMM/Is

To investigate the genetic characteristics of AMM/I in detail, we conducted microarray analysis compared with untreated AMMs (Fig. 2A). The global gene expression analysis revealed that $I L-10$ ( 94.5 -fold) was the most highly expressed gene, suggesting successful integration of the $I L-10$ gene in the AAVS1 locus (Table 1). However, we detected relatively low levels of other genes (less than 6-fold) such as NPNT, KDM4C, PCDH7, and CRABP1. These data indicate that TALEN-mediated gene integration does not allow severe off-target mutagenesis in target cells.

Next, to evaluate the quantity of IL-10 secreted by AMM/I, we conducted ELISA. ELISA detected significantly higher levels of IL-10 in AMM/I CM than in AMM CM (Fig. 2B).

\section{AMM/I suppress inflammation in the ischemic myocardium}

To examine the anti-inflammatory effects of AMM/I in cardiac tissue, we induced mice MI models and performed immunohistochemical staining using CD68 antibody 3 days after cell injection. Lower numbers of infiltrated CD68-positive cells (Fig. 3A and 3B) and F4/80positive cells (Fig. 3C and 3D) were detected in the AMM/I-injected mice than in the AMMand PBS-injected mice in the border zone of the infarcted $\mathrm{LV}$ heart tissues. In addition, higher levels of IL-10 protein and mRNA were detected in AMM/I injected LV heart tissues than in AMM injected LV heart tissues (Fig. 3E and 3F).

Next, we also measured the mRNA expression levels of pro-inflammatory factors in the infarcted heart tissues 3 days after cell injection. The AMM/I-injected mice showed significantly lower IL-1 $\beta$, IL-6, and TNF- $\alpha$ mRNA expressions than did the AMM- and PBSinjected mice in infarcted heart tissues (Fig. 3G).

Table 1. Top 5 up-regulated genes list in AMM/I compared with AMMs

\begin{tabular}{lccc}
\hline Probe ID & Gene Symbol & Description & Fold Change \\
\hline TC0100017107.hg.1 & IL10 & Interleukin 10 & 94.5 \\
TC0400008331.hg.1 & NPNT & Nephronectin & 5.5 \\
TC0900009505.hg.1 & KDM4C & Lysine-specific demethylase 4C & 3.3 \\
TC0400007169.hg.1 & PCDH7 & Protocadherin 7 & 3.1 \\
TC1500007972.hg.1 & CRABP1 & 3-hydroxyacyl-CoA dehydratase 4 & 2.5 \\
\hline
\end{tabular}

Fig. 2. Global gene expression profile of AMM/I. (A) Heat map results after microarray analysis. (B) ELISA for IL-10 in the AMM/I and AMM. The amount of IL-10 was markedly higher in AMM/I than AMM. ${ }^{* *}$ p < $0.01 ; \mathrm{n}=4$ per group.

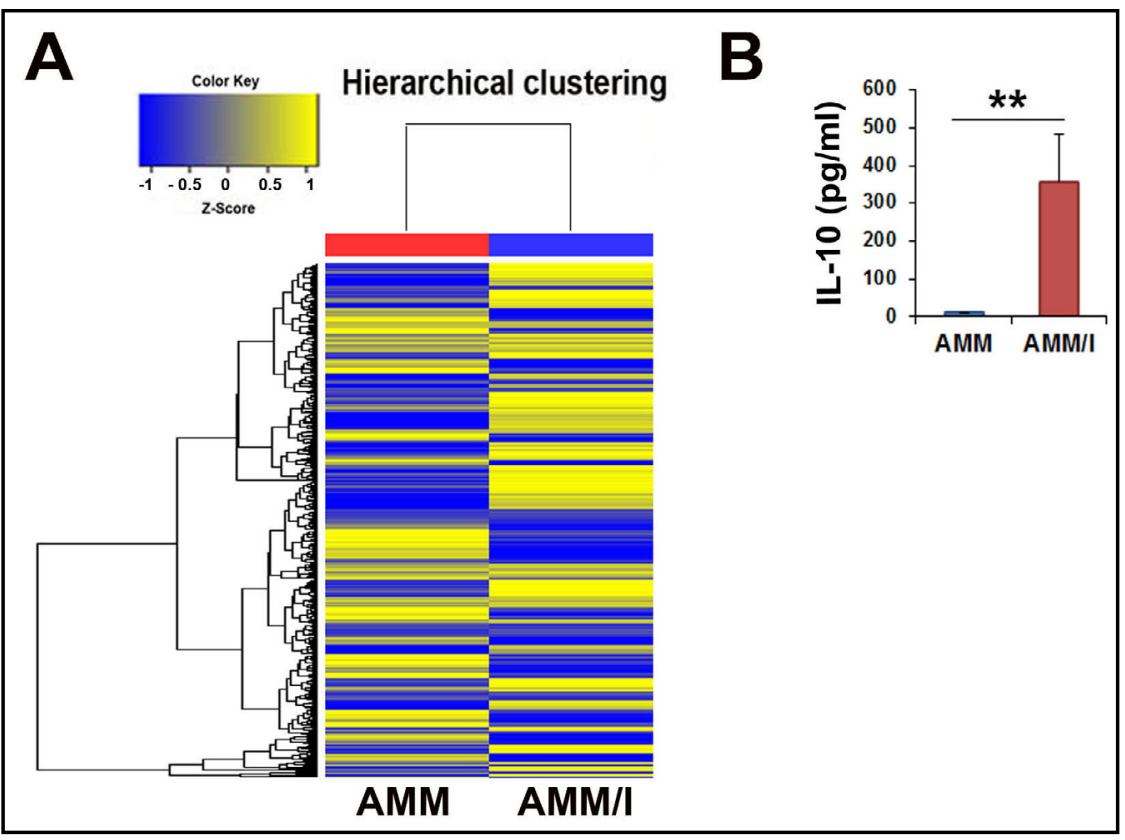


Fig. 3. Antiinflammatory activity of AMM/I in MI. (A) Representative pictures of the infiltrated inflammatory cells (CD68-positive, green color) 3 days after cell injection in MI heart tissues. Bars: $50 \mu \mathrm{m}$. (B) Quantitative analysis of infiltrated CD68positive inflammatory cells 3 days after cell injection in MI heart tissues. HPF, high-power field. ${ }^{* *} \mathrm{p}<0.01,{ }^{*} \mathrm{p}<0.05$; $\mathrm{n}=7$ per group. (C) Representative pictures of the infiltrated inflammatory cells (CD68-positive, green color) 3 days after cell injection in MI heart tissues. Bars: $50 \mu \mathrm{m}$. (D) Quantitative analysis of infiltrated F4/80positive inflammatory cells 3 days after cell injection in MI heart tissues. $\quad{ }^{* *} \mathrm{p}<0.01$, ${ }^{*} \mathrm{p}<0.05 ; \mathrm{n}=6$ per group. (E) ELISA for IL-10 in the AMM/I and AMM injected LV heart tissues. The amount of IL-10 was markedly higher in the AMM/I injected tissues than AMM injected

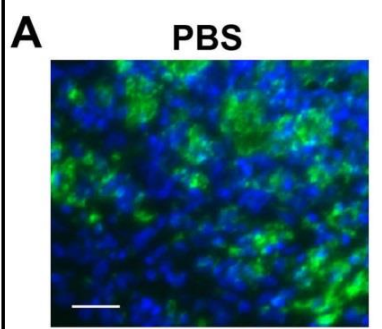

\section{AMM/I}

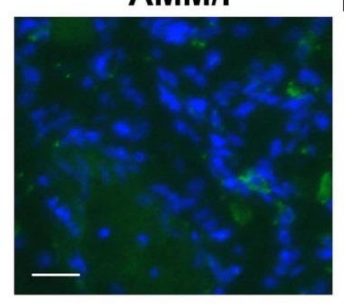

\section{B}
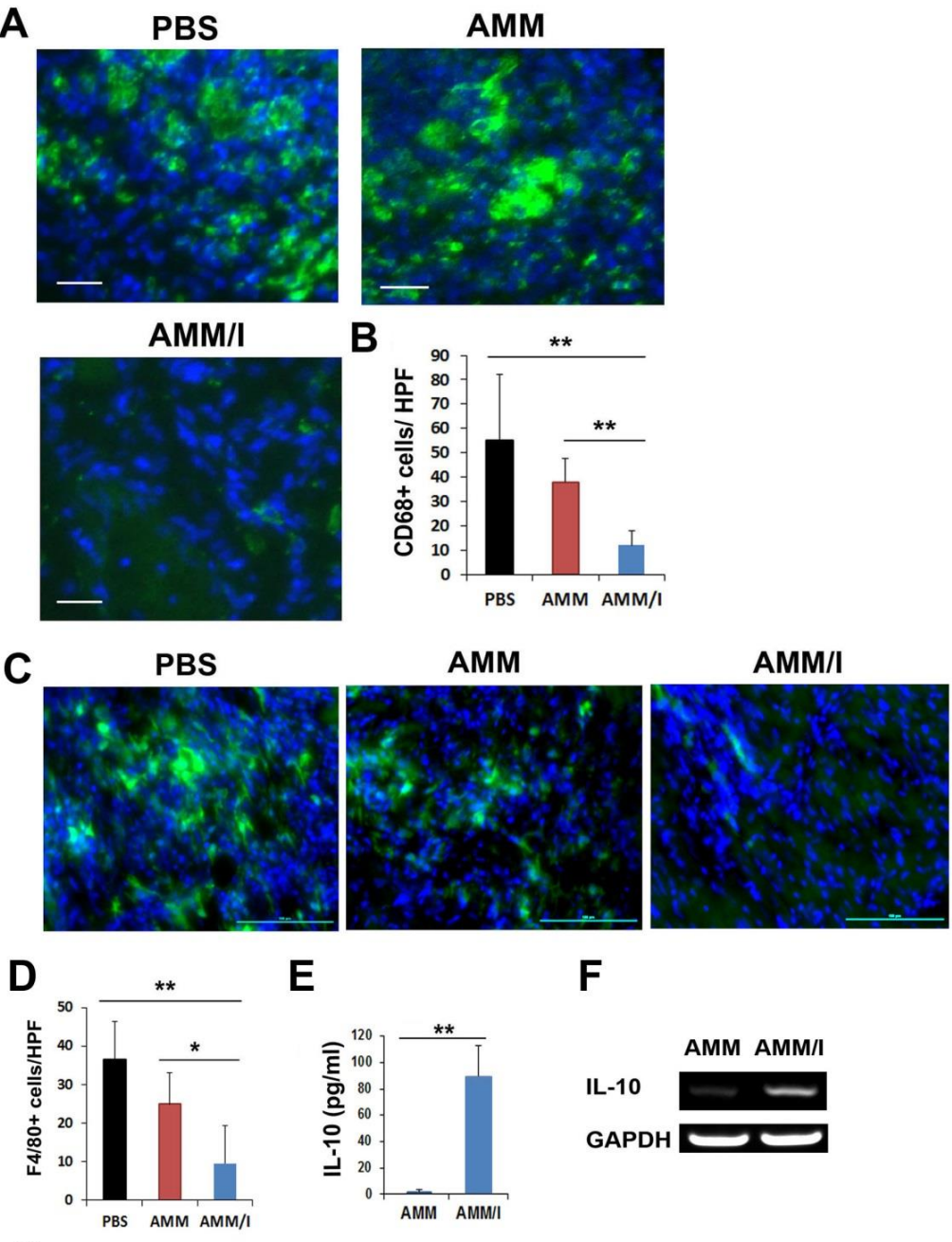

E

$\mathbf{F}$
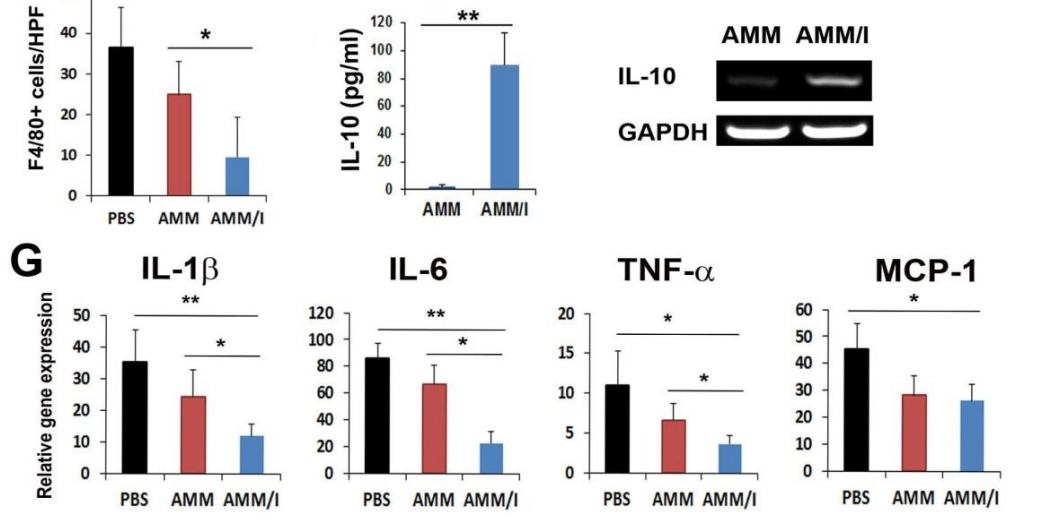

tissues groups. $n=6$ per

group. (F) IL-10 mRNA (RT-PCR) expression levels were detected in the AMM/I and AMM injected LV heart tissues. (G) qRT-PCR results from the samples harvested from the mice heart tissues of at 3 days after cell injection in MI. ${ }^{* *} \mathrm{p}<0.01,{ }^{*} \mathrm{p}<0.05 ; \mathrm{n}=5$ per group.

\section{AMM/I exert favorable therapeutic effects in MI model}

To examine the therapeutic effects of AMM/I in MI, the LV function was examined by echocardiography at 2 and 4 weeks. AMM- and PBS-injected mice were used as control groups. We could not find any significant differences in LV function at 2 weeks. However, echocardiography data at 4 weeks showed that the EF and FS were significantly greater in the AMM/I-injected mice compared with that of the AMM- or PBS-injected mice (Fig. 4A and 4B). 
Fig. 4. Therapeutic effects of AMM/I in MI. (A) Representative echocardiographic images 4 weeks after cell injection in MI. (B) Analysis results of left ventricular fractional shortening (LVFS) and left ventricular ejection fraction (LVEF) calculations. ${ }^{* *} \mathrm{p}<0.01,{ }^{*} \mathrm{p}<0.05 ; \mathrm{n}=7$ per group.

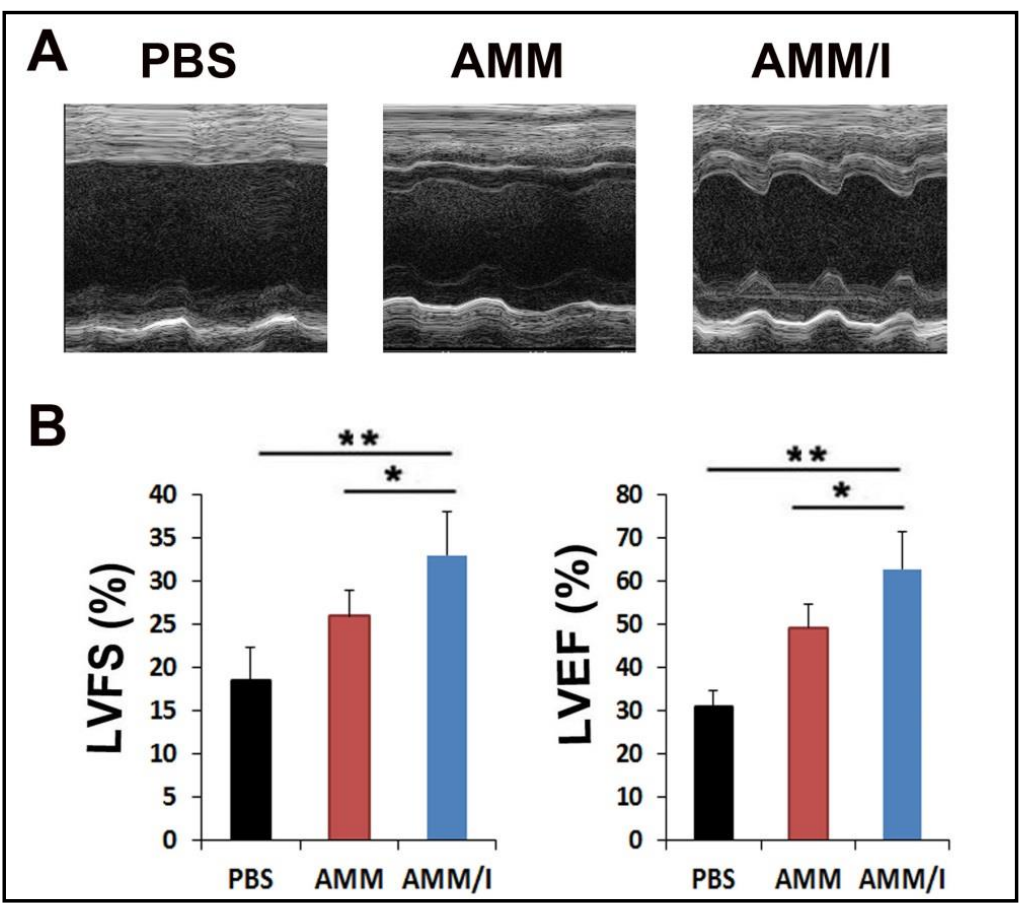

Fig. 5. Anti-fibrosis effects of AMM/I in MI. (A) Representative crosssectional images 4 weeks after cell injection. The mouse hearts were stained by Mason's trichrome (MT). (B) Quantification of fibrosis area from MT staining. ${ }^{* *} \mathrm{p}<0.01,{ }^{*} \mathrm{p}<0.05 ; \mathrm{n}=5$ per group.

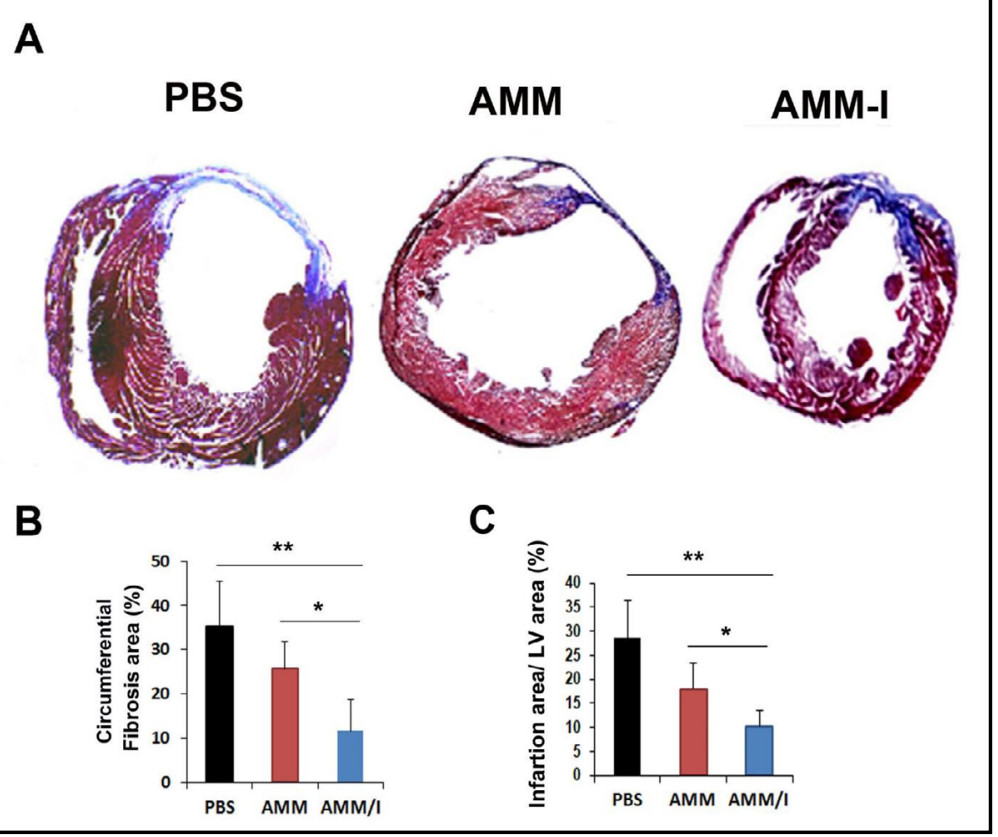

Next, the infarct size in the heart tissue was also measured after cell injection at 4 weeks post-MI using Mason's trichrome (MT) staining. MT staining results revealed that the significantly lower circumferential fibrosis area and infarction area were detected in AMM/Iinjected mice compared with that of the AMM- and PBS-injected mice (Fig. 5A, 5B and 5C).

AMM/I injection decreases apoptotic cells and increases vascular density in ischemic heart

Because decreased infarct areas in heart tissue are associated with cell apoptosis, TUNEL assay was conducted using tissue sections harvested at 4 weeks. The apoptotic cells at the peri-infract area were significantly lower in the AMM/I-injected mice group than in 


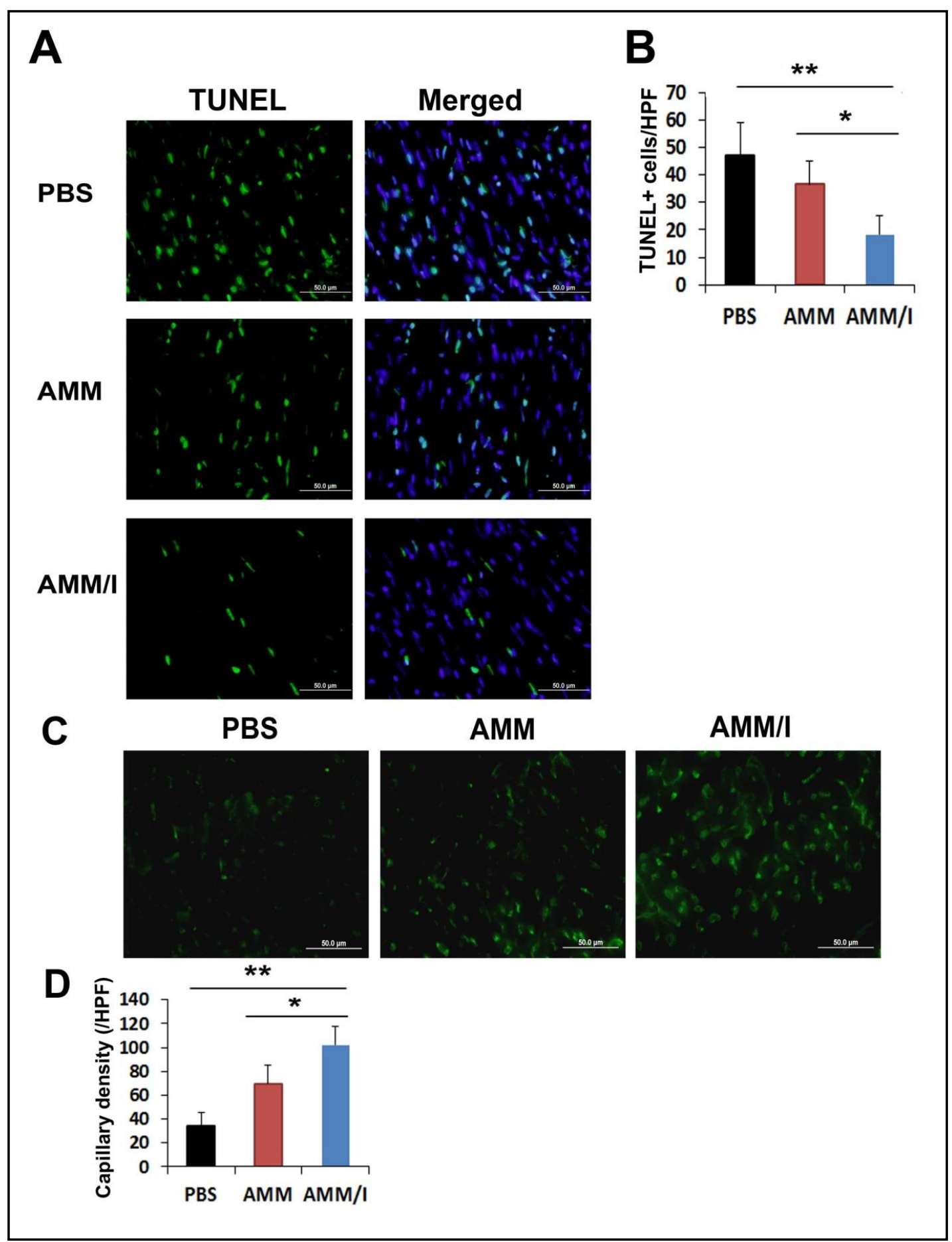

Fig. 6. Anti-apoptotic and angiogenic properties of AMM/I. (A) Representative pictures after TUNEL staining on peri-infarcted heart tissues 4 weeks after cell injection. Bars: $50 \mu \mathrm{m}$. (B) Quantification of TUNEL-positive cells. ${ }^{* *} \mathrm{p}<0.01,{ }^{*} \mathrm{p}<0.05 ; \mathrm{n}=10$ per group. (C) Representative pictures after ILB4 staining on peri-infarcted heart tissues 4 weeks after cell injection. Bars: $50 \mu \mathrm{m}$. (D) Quantification of ILB4-positive cells. ${ }^{* *} \mathrm{p}<0.01$, $* \mathrm{p}<0.05 ; \mathrm{n}=5$ per group. 


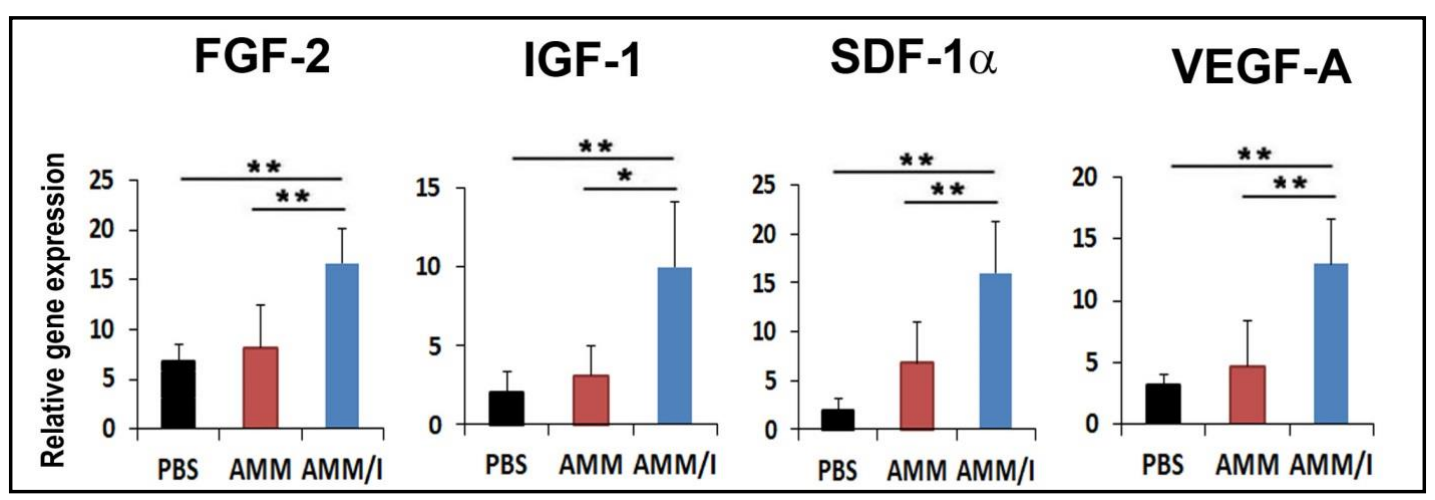

Fig. 7. In vivo angiogenic property of AMM/I. qRT-PCR results with peri-infarct cardiac tissues 4 weeks after injected with AMM/I, AMMs, and PBS. ${ }^{* *} \mathrm{p}<0.01,{ }^{*} \mathrm{p}<0.05 ; \mathrm{n}=5$ per group.

the AMM- and PBS-injected groups (Fig. 6A and 6B). Capillary density was also observed post-AMM transplantation in ischemic heart tissues. Interestingly, vascular density in the border zone of the ischemic heart area was significantly higher in the AMM/I-injected mice than that of the AMM- and PBS-treated mice (Fig. 6C and 6D).

To determine the angiogenic humoral effects after AMM/I injection on MI mice, ischemic cardiac tissues were prepared at 4 weeks after cell injection. Interestingly, the mRNA expression levels of FGF-2, IGF-1, SDF-1 $\alpha$ and VEGF-A were significantly upregulated in the AMM/I-injected ischemic cardiac tissues compared with the AMM- or PBS-injected cardiac tissues (Fig. 7). These data suggest that direct cardiac injection of AMM/I also influences the enhanced multiple pro-angiogenic factors.

\section{Discussion}

In the present study, we first demonstrated that $I L-10$-edited AMMs exhibited robust anti-inflammatory activity, suggesting that this could be one of the promising therapeutic options in the treatment of ischemic heart disease. The major results of this study are as follows: (1) We successfully generated sustainable $I L-10$-expressing AMM cell line via genome editing. (2) AMM/I showed anti-inflammatory properties in AMI mice models. (3) AMM/I transplantation into the AMI mice model resulted in enhanced recovery of heart function and attenuated LV remodeling. (4) The transplanted AMM/I lessened the inflammatory response and provided a favorable environment for neovascularization.

One challenging issue in stem cell therapy is its marginal influence in treating various ischemic or chronic diseases. To overcome this limitation, genetic modification has been regarded as an attractive tool as it can provide protein replacement as a cellular vehicle. However, genetic modification also has been limited by random insertional mutagenesis. Until recently, to remove the risk of genomic mutagenesis in genetic modification, the technology of targeted gene insertion at safe-harbor genomic sites, namely, gene editing, has generated great interest. For gene insertion, only few genomic sites are safe and in an open chromosomal status to achieve high gene expression. In fact, erythropoietin gene-edited MSCs, hepatocyte growth factor gene-edited MSCs, and chemokine gene-edited AMM cell lines were recently generated for therapeutic proteins by zinc finger nuclease or TALEN mediators $[11,23]$. In agreement with these studies, we were also able to successfully generate (TALEN-mediated) IL-10-integrated AMM lines without high-level genetic mutagenesis in the genome, as confirmed by the global gene expression profile derived from the microarray data. However, AMM/I expressed several genes less than 6-folds when compared to untreated AMMs, indicating a relatively low level of off-target mutagenesis or innate cellular autocrine influence of $I L-10$ in AMMs. These results are in agreement with a previous report that the incidence of off-target mutation is sufficiently low for the TALEN- 


\section{Cellular Physiology Cell Physiol Biochem 2019;52:728-741 \\ \begin{tabular}{ll|l} 
and Biochemistry & $\begin{array}{l}\text { DOl: 10.33594/000000051 } \\
\text { Published online: 29 March 2019 }\end{array}$ & $\begin{array}{l}\text { O } 2019 \text { The Author(s). Published by } \\
\text { Cell Physiol Biochem Press GmbH\&Co. KG }\end{array}$ \\
\cline { 2 - 3 } &
\end{tabular} \\ Meng et al.: IL-10 Edited MSCs Attenuates Left Ventricular Remodeling}

mediated genome editing in stem cells, and thus, it is not a significant concern for application [12].

According to recent reports, LV remodeling such as cardiomyocyte hypertrophy is strongly associated with inflammatory response that alters gene expression and induces contractile abnormalities and ventricular dysfunction $[24,25]$. Inflammatory cell infiltration was also strongly associated with increase in stress-activated cytokines, such as IL-1 $\beta$, IL6 , TNF- $\alpha$, and MCP-1, produced by cardiomyocytes and inflammatory cells [26]. In fact, T-lymphocytes derived from post-MI resulted in cytotoxicity of the cardiac myocytes [27]. To reduce the inflammatory reaction in the injury site, $I L-10$ was used. $I L-10$ administration attenuated the infiltration of inflammatory cells in the vascular injury model [28]. In line with this study, AMM/I injection inhibited the infiltration of CD68-positive monocyte/ macrophages and the expression of pro-inflammatory cytokines in the border zone of the ischemic myocardium.

Cytokines contribute to adverse LV remodeling and contractile performance through its effects on calcium-mediated cardiac contractility [29, 30]. $I L-10$ administration attenuated left ventricular remodeling after MI [26], and injection of $I L-10$-secreting bone marrow mononuclear cells improved cardiac function in infarcted mouse hearts, which led to a significant improvement in cardiac function [31]. In the present study, AMM/I transplantation also attenuated the decrease of FS and EF after MI. These findings strongly support the evidence of the cardioprotective effects of $I L-10$ on infarcted heart tissue. However, more studies on $I L-10$ and a more detailed study of the therapeutic mechanisms such as calciummediated cardiac contractility might be required.

Neovascularization is an essential part for the healing process of an ischemic heart, and $I L-10$ treatment increased CD31-positive capillaries at 4 weeks post-MI [26]. Other studies also reported the involvement of inflammatory mediators in myocyte apoptosis or necrosis in the progression of adverse LV remodeling [32] and that $I L-10$ treatment decreased the apoptotic cells in the MI mice model [26]. Recently, the robust angiovasculogenic and chemotactic properties of AMMs themselves have been reported [33, 34]. In line with these previous reports, in the present study, increased capillary density, pro-angiogenic factors, and lower apoptotic cells in ischemic cardiac tissues were observed in the AMM/I-treated MI group than in AMM-treated MI group. These results suggest that an anti-inflammatory environment could lead to synergistic effects for optimal neovascularization in MI.

These results are similar to previously reported data that human cultured BM-derived CD31 ${ }^{+}$cells, which possess both angiogenic and anti-inflammatory properties, are effective for cardiac and vascular repair [21]. Thus, AMM/I have the potential of robust cardiac protection by secreting the angiogenic $[33,34]$ and anti-inflammatory factor IL-10. The immune-regulatory mechanism regarding IL10 and infiltrating inflammatory cells in heart tissues has been elucidated by emerging research. IL-10 modulates the secretion of Th1 and Th2 cell cytokines and activation/proliferation of T lymphocytes [35]. Previous studies have demonstrated that IL-10 null mice showed $75 \%$ mortality due to the larger infarct size and increased plasma levels of TNF- $\alpha$, indicating enhanced inflammation [36]. Our data also demonstrated that IL-10 derived from AMM/I acted via modulation of infiltrating inflammatory cells such as $\mathrm{CD}^{+} 8^{+}$or $\mathrm{F} 4 / 80^{+}$macrophages and contributed to cardiac protection and paracrine activities of infused cells after MI.

\section{Conclusion}

Taken together, the present study suggests that AMM/I produced by gene editing contributes to the prevention of $\mathrm{LV}$ remodeling and to cardiac protection by the attenuation of severe pro-inflammatory responses with effects on angiogenesis after MI. Accordingly, AMM/I generated by TALEN gene editing might be a highly promising and therapeutic option to treat MI. Further studies might be required to determine whether AMM/I are safe and capable of treating ischemic cardiovascular disease in the clinical setting. 


\section{Cellular Physiology Cell Physiol Biochem 2019;52:728-741

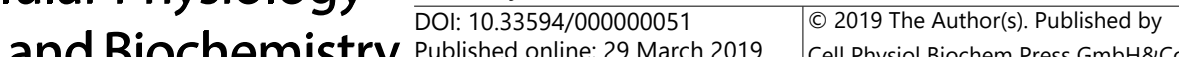 \\ \begin{tabular}{ll} 
Published online: 29 March 2019 Cell Physiol Biochem Press GmbH\&Co. KG \\
\hline
\end{tabular} \\ Meng et al.: IL-10 Edited MSCs Attenuates Left Ventricular Remodeling}

\section{Acknowledgements}

This work was financially supported through National Research Foundation of Korea (NRF) grants funded by the Korean Government (No. NRF-2016R1A2B4012683 and No. NRF-2015M3A9E6029558), the research fund of Dong-A University and the research fund of Catholic Kwandong University.

S-W K. designed and supervised the experiments. DM and SH performed the experiments, analyzed the data and wrote the manuscript. ISJ performed the experiments. All authors read and approved the final manuscript.

\section{Disclosure Statement}

The authors declare that they have no competing interests.

\section{References}

- 1 Timmers L, Sluijter JP, van Keulen JK, Hoefer IE, Nederhoff MG, Goumans MJ, Doevendans PA, van Echteld CJ, Joles JA, Quax PH, Piek JJ, Pasterkamp G, de Kleijn DP: Toll-like receptor 4 mediates maladaptive left ventricular remodeling and impairs cardiac function after myocardial infarction. Circ Res 2008;102:257264.

- 2 Huebener P, Abou-Khamis T, Zymek P, Bujak M, Ying X, Chatila K, Haudek S, Thakker G, Frangogiannis NG: CD44 is critically involved in infarct healing by regulating the inflammatory and fibrotic response. J Immunol 2008;180:2625-2633.

3 Tao ZY, Cavasin MA, Yang F, Liu YH, Yang XP: Temporal changes in matrix metalloproteinase expression and inflammatory response associated with cardiac rupture after myocardial infarction in mice. Life Sci 2004;74:1561-1572.

4 Matsumura S, Iwanaga S, Mochizuki S, Okamoto H, Ogawa S, Okada Y: Targeted deletion or pharmacological inhibition of MMP-2 prevents cardiac rupture after myocardial infarction in mice. J Clin Invest 2005;115:599-609.

- 5 Li Y, Takemura G, Okada H, Miyata S, Maruyama R, Li L, Higuchi M, Minatoguchi S, Fujiwara T, Fujiwara H: Reduction of inflammatory cytokine expression and oxidative damage by erythropoietin in chronic heart failure. Cardiovasc Res 2006;71:684-694.

- 6 Pittenger MF, Mackay AM, Beck SC, Jaiswal RK, Douglas R, Mosca JD, Moorman MA, Simonetti DW, Craig S, Marshak DR: Multilineage potential of adult human mesenchymal stem cells. Science 1999;284:143-147.

7 da Silva Meirelles L, Chagastelles PC, Nardi NB: Mesenchymal stem cells reside in virtually all post-natal organs and tissues. J Cell Sci 2006;119:2204-2213.

- 8 Lee KD, Kuo TK, Whang-Peng J, Chung YF, Lin CT, Chou SH, Chen JR, Chen YP, Lee OK: In vitro hepatic differentiation of human mesenchymal stem cells. Hepatology 2004;40:1275-1284.

9 Di Nicola M, Carlo-Stella C, Magni M, Milanesi M, Longoni PD, Matteucci P, Grisanti S, Gianni AM: Human bone marrow stromal cells suppress T-lymphocyte proliferation induced by cellular or nonspecific mitogenic stimuli. Blood 2002;99:3838-3843.

10 Frangogiannis NG, Mendoza LH, Lindsey ML, Ballantyne CM, Michael LH, Smith CW, Entman ML: IL10 is induced in the reperfused myocardium and may modulate the reaction to injury. J Immunol 2000;165:2798-2808.

11 Chang HK, Kim PH, Cho HM, Yum SY, Choi YJ, Son Y, Lee D, Kang I, Kang KS, Jang G, Cho JY: Inducible HGFsecreting Human Umbilical Cord Blood-derived MSCs Produced via TALEN-mediated Genome Editing Promoted Angiogenesis. Mol Ther 2016;24:1644-1654.

- 12 Veres A, Gosis BS, Ding Q, Collins R, Ragavendran A, Brand H, Erdin S, Cowan CA, Talkowski ME, Musunuru K: Low incidence of off-target mutations in individual CRISPR-Cas9 and TALEN targeted human stem cell clones detected by whole-genome sequencing. Cell Stem Cell 2014;15:27-30. 


\section{Cellular Physiology Cell Physiol Biochem 2019;52:728-741 \begin{tabular}{ll|l|l|l} 
DOI: 10.33594/000000051 2019 The Author(s). Published by \\
and Biochemistry Published online: 29 March 2019 & Cell Phys
\end{tabular} and Biochemistry Published online: 29 March 2019 Cell Physiol Biochem Press GmbH\&Co. KG \\ Meng et al.: IL-10 Edited MSCs Attenuates Left Ventricular Remodeling}

- 13 Kim SW, Kim H, Cho HJ, Lee JU, Levit R, Yoon YS: Human peripheral blood-derived CD31+ cells have robust angiogenic and vasculogenic properties and are effective for treating ischemic vascular disease. J Am Coll Cardiol 2010;56:593-607.

- 14 Seo SK, Kim N, Lee JH, Kim SM, Lee SY, Bae JW, Hwang KK, Kim DW, Koch WJ, Cho MC: beta-arrestin2 Affects Cardiac Progenitor Cell Survival through Cell Mobility and Tube Formation in Severe Hypoxia. Korean Circ J 2018;48:296-309.

- 15 Rao Z, Wang S, Bunner WP, Chang Y, Shi R: Exercise induced Right Ventricular Fibrosis is Associated with Myocardial Damage and Inflammation. Korean Circ J 2018;48:1014-1024.

- 16 Cho HJ, Lee N, Lee JY, Choi YJ, Ii M, Wecker A, Jeong JO, Curry C, Qin G, Yoon YS: Role of host tissues for sustained humoral effects after endothelial progenitor cell transplantation into the ischemic heart. J Exp Med 2007;204:3257-3269.

17 Jeong JO, Han JW, Kim JM, Cho HJ, Park C, Lee N, Kim DW, Yoon YS: Malignant tumor formation after transplantation of short-term cultured bone marrow mesenchymal stem cells in experimental myocardial infarction and diabetic neuropathy. Circ Res 108:1340-1347.

18 Jeong JO, Kim MO, Kim H, Lee MY, Kim SW, Ii M, Lee JU, Lee J, Choi YJ, Cho HJ, Lee N, Silver M, Wecker A, Kim DW, Yoon YS: Dual angiogenic and neurotrophic effects of bone marrow-derived endothelial progenitor cells on diabetic neuropathy. Circulation 2009;119:699-708.

- 19 Yoon YS, Wecker A, Heyd L, Park JS, Tkebuchava T, Kusano K, Hanley A, Scadova H, Qin G, Cha DH, Johnson KL, Aikawa R, Asahara T, Losordo DW: Clonally expanded novel multipotent stem cells from human bone marrow regenerate myocardium after myocardial infarction. J Clin Invest 2005;115:326-338.

20 Ji N, Lou H, Gong X, Fu T, Ni S: Treatment with 3-Bromo-4, 5-Dihydroxybenzaldehyde Improves Cardiac Function by Inhibiting Macrophage Infiltration in Mice. Korean Circ J 2018;48:933-943.

21 Kim SW, Houge M, Brown M, Davis ME, Yoon YS: Cultured human bone marrow-derived CD31(+) cells are effective for cardiac and vascular repair through enhanced angiogenic, adhesion, and anti-inflammatory effects. J Am Coll Cardiol 2014;64:1681-1694.

22 Nascimento DS, Valente M, Esteves T, de Pina Mde F, Guedes JG, Freire A, Quelhas P, Pinto-do-Ó P: MIQuant-semi-automation of infarct size assessment in models of cardiac ischemic injury. PLoS One 2011;6:e25045.

23 Benabdallah BF, Allard E, Yao S, Friedman G, Gregory PD, Eliopoulos N, Fradette J, Spees JL, Haddad E, Holmes MC, Beausejour CM: Targeted gene addition to human mesenchymal stromal cells as a cell-based plasma-soluble protein delivery platform. Cytotherapy 2010;12:394-399.

24 Sun M, Chen M, Dawood F, Zurawska U, Li JY, Parker T, Kassiri Z, Kirshenbaum LA, Arnold M, Khokha R, Liu PP: Tumor necrosis factor-alpha mediates cardiac remodeling and ventricular dysfunction after pressure overload state. Circulation 2007;115:1398-1407.

- 25 Suzuki K, Murtuza B, Smolenski RT, Sammut IA, Suzuki N, Kaneda Y, Yacoub MH: Overexpression of interleukin-1 receptor antagonist provides cardioprotection against ischemia-reperfusion injury associated with reduction in apoptosis. Circulation 2001;104:I308-I313.

26 Krishnamurthy P, Rajasingh J, Lambers E, Qin G, Losordo DW, Kishore R: IL-10 inhibits inflammation and attenuates left ventricular remodeling after myocardial infarction via activation of STAT3 and suppression of HuR. Circ Res 2009;104:e9-e18.

27 Varda-Bloom N, Leor J, Ohad DG, Hasin Y, Amar M, Fixler R, Battler A, Eldar M, Hasin D: Cytotoxic T lymphocytes are activated following myocardial infarction and can recognize and kill healthy myocytes in vitro. J Mol Cell Cardiol 2000;32:2141-2149.

28 Rajasingh J, Bord E, Luedemann C, Asai J, Hamada H, Thorne T, Qin G, Goukassian D, Zhu Y, Losordo DW, Kishore R: IL-10-induced TNF-alpha mRNA destabilization is mediated via IL-10 suppression of p38 MAP kinase activation and inhibition of HuR expression. FASEB J 2006;20:2112-2114.

29 Sun M, Dawood F, Wen WH, Chen M, Dixon I, Kirshenbaum LA, Liu PP: Excessive tumor necrosis factor activation after infarction contributes to susceptibility of myocardial rupture and left ventricular dysfunction. Circulation 2004;110:3221-3228.

30 Sugishita K, Kinugawa K, Shimizu T, Harada K, Matsui H, Takahashi T, Serizawa T, Kohmoto O: Cellular basis for the acute inhibitory effects of IL-6 and TNF- alpha on excitation-contraction coupling. J Mol Cell Cardiol 1999;31:1457-1467.

31 Burchfield JS, Iwasaki M, Koyanagi M, Urbich C, Rosenthal N, Zeiher AM, Dimmeler S: Interleukin-10 from transplanted bone marrow mononuclear cells contributes to cardiac protection after myocardial infarction. Circ Res 2008;103:203-211. 


\section{Cellular Physiology and Biochemistry}

Cell Physiol Biochem 2019;52:728-741

32 Yeh CH, Chen TP, Wu YC, Lin YM, Jing Lin P: Inhibition of NFkappaB activation with curcumin attenuates plasma inflammatory cytokines surge and cardiomyocytic apoptosis following cardiac ischemia/ reperfusion. J Surg Res 2005;125:109-116.

33 Lee KB, Choi JH, Byun K, Chung KH, Ahn JH, Jeong GB, Hwang IK, Kim S, Won MH, Lee B: Recovery of CNS pathway innervating the sciatic nerve following transplantation of human neural stem cells in rat spinal cord injury. Cell Mol Neurobiol 2012;32:149-157.

34 Kim SW, Zhang HZ, Kim CE, Kim JM, Kim MH: Amniotic mesenchymal stem cells with robust chemotactic properties are effective in the treatment of a myocardial infarction model. Int J Cardiol 2013;168:10621069.

35 Beyth S, Borovsky Z, Mevorach D, Liebergall M, Gazit Z, Aslan H, Galun E, Rachmilewitz J: Human mesenchymal stem cells alter antigen-presenting cell maturation and induce T-cell unresponsiveness. Blood 2005;105:2214-2219.

36 Yang Z, Zingarelli B, Szabo C: Crucial role of endogenous interleukin-10 production in myocardial ischemia/reperfusion injury. Circulation 2000;101:1019-1026. 